\title{
Modern Rhodolith-dominated carbonates at Punta Chivato, Mexico
}

\author{
Jochen HALFAR \\ University of Toronto, Department of Chemical and Physical Sciences, \\ 3359 Mississauga Rd. N, Mississauga, L5L 1C6 (Canada) \\ jochen.halfar@utoronto.ca \\ Markus EISELE \\ MARUM, University of Bremen, \\ Leobener Strasse, D-28334 Bremen (Germany) \\ meisele@uni-bremen.de \\ Bernhard RIEGL \\ National Coral Reef Institute, \\ Nova Southeastern University Oceanographic Center, \\ 8000 North Ocean Drive, FL-33004 Dania Beach (USA) \\ rieglb@nova.edu
}

Steffen HETZINGER

University of Toronto, Department of Chemical and Physical Sciences, 3359 Mississauga Rd. N, Mississauga, L5L 1C6 (Canada) and IFM-GEOMAR, Leibniz-Institut für Meereswissenschaften,

Wischhofstr. 1-3, D-24148 Kiel (Germany) shetzinger@ifm-geomar.de

Lucio GODINEZ-ORTA

Centro Interdisciplinario de Ciencias Marinas, Av. IPN s/n Apdo. Postal 592, La Paz, B.C.S., 23096 Mexico (Mexico) lorta@ipn.mx

\footnotetext{
Halfar J., Eisele M., Riegl B., Hetzinger S. \& Godinez-Orta L. 2012. - Modern Rhodolithdominated carbonates at Punta Chivato, Mexico. Geodiversitas 34 (1): 99-113. http://dx.doi. org/10.5252/g2012n1a6
}

\begin{abstract}
Rhodolith-dominated carbonate environments, characterized by high abundances of free-living coralline algae, have been described globally from a wide range of Recent and fossil shallow marine settings. In the present-day warm-temperate Gulf of California, Mexico, rhodolith-dominated systems
\end{abstract}


KEY WORDS

Gulf of California,

coralline algae, acoustic mapping, rhodalgal.
MOTS CLÉS

golfe de Californie, algues corallines, cartographie acoustique, faciès rhodalgal. are important contributors to carbonate production. One of the most prolific rhodolith factories is located on the Punta Chivato shelf, in the central Gulf of California, where due to a lack of input of terrigenous material from the arid hinterland, carbonate content averages 79\%. Punta Chivato rhodoliths thrive above the shallow euphotic zone under normal saline, warm-temperate and meso- to eutrophic conditions. A detailed sedimentologic study combined with acoustic seafloor mapping indicates the presence of extensive rhodolith-dominated facies at subtidal water depth covering an area of $>17 \mathrm{~km}^{2}$. Additional facies, surrounding the rhodolith-dominated facies include a fine-grained molluscan, a transitional bivalve-rhodolith and a bivalve facies. While the Punta Chivato shelf yields average abundances of $38 \%$ rhodolith-derived coralline algal components in the gravel-sized sediment fraction, the rhodolith facies itself is characterized by more than $60 \%$ coralline algal components. Other important carbonate producers at Punta Chivato include bivalves (35\%), bryozoa (11\%) and gastropods ( $8 \%)$. The present study shows that acoustic sediment mapping yields highly resolved continuous coverage of the seafloor and can distinguish modern rhodolith facies from surrounding sediment. This has important implications for quantifying rhodolith-dominated settings globally, as well as for ecological and conservation studies.

\section{RÉSUMÉ}

\section{Les faciès carbonatés actuels à rhodolithes de Punta Chivato, Mexique.}

Des exemples d'environnements carbonatés à rhodolithes dominants, caractérisés par la grande abondance des algues corallines, ont été répertoriés au sein d'une large gamme d'environnements marins peu profonds, modernes ou fossiles. Aujourd'hui, dans les eaux chaudes du golfe de Californie (Mexique), ces systèmes contribuent de façon significative à la production carbonatée. Une des «fabriques " à rhodolithes parmi les plus productrices est située sur la plate-forme de Punta Chivato, dans la partie centrale du golfe de Californie, là où, l'aridité de l'arrière-pays limitant fortement les apports terrigènes, la proportion de carbonates tourne autour de $79 \%$. Les rhodolithes de Punta Chivato prospèrent dans la zone euphotique peu profonde, dans des eaux chaudes à salinité normale, et dans des conditions méso- à eutrophiques. Une étude sédimentologique détaillée combinée à une cartographie acoustique indique que les zones à rhodolithes dominants s'étendent dans la zone subtidale sur une surface supérieure à $17 \mathrm{~km}^{2}$. À la périphérie des secteurs à rhodolithes dominants, on observe d'autres types de faciès: 1) un faciès sablonneux à mollusques; 2) un faciès à mollusques bivalves et rhodolithes; et 3) un faciès à mollusques bivalves seuls. Si nous considérons alors, sur la plate-forme de Punta Chivato dans son grand ensemble, qu'en moyenne $38 \%$ des débris d'origine algaire se rangent dans la catégorie granulométrique des graviers et galets, cette fraction dépasse $60 \%$ pour le faciès à rhodolithes. Les mollusques bivalves (35\%), les Bryozoaires (11\%) et les Gastéropodes (6\%) complètent le tableau. Notre étude montre que la cartographie acoustique des sédiments fournit une couverture continue à haute résolution du fond marin et permet de distinguer les faciès à rhodolithes des sédiments qui les encadrent. Cette approche est intéressante pour qui voudrait quantifier les zones à rhodolithes, tant à des fins écologiques que pour leur préservation. 


\section{INTRODUCTION}

Global occurrences of modern rhodolith-dominated carbonate systems (rhodoliths = free-living coralline algae) have been compiled by Bosence (1983) and Foster (2001). In many of these systems, rhodoliths exhibit patchy distribution patterns and are found in distinct so-called "rhodolith beds", which are loosely defined as accumulations of living and dead unattached coralline algae (Steller \& Foster 1995; Foster et al. 1997). While a modern rhodolith environment is considered a "bed" when rhodolith cover exceeds 10\% (Steller et al. 2009) the minimum spatial extent for a rhodolith accumulation to be considered a "bed" has not been defined. Accordingly, the spatial extent of "beds" described in the literature varies from less than a few hundred $\mathrm{m}^{2}$ to several $\mathrm{km}^{2}$. Only the larger "beds" (e.g., $>1 \mathrm{~km}^{2}$ ) would likely be recognized as a distinct facies in ancient deposits. In the fossil record, the term "Rhodalgal" lithofacies - dominated by encrusting coralline algae (Rhodophyta) which often form rhodoliths - has commonly been applied (Carannante et al. 1988). Fossil analogues of modern rhodalgal carbonate sediments are widespread globally (Halfar \& Mutti 2005) and in the Gulf of California (Johnson et al. 2009) and have frequently been reported from numerous outcrops from the Paleotethys region (Bosence \& Pedley 1979; Carannante et al. 1988; Esteban 1996; Fornos \& Ahr 1997; Betzler et al. 1997; Wilson 2002; Rasser \& Piller 2004; Pomar et al. 2004; Basso et al. 2006, 2008; Nalin et al. 2008).

Rhodolith systems support a high biodiversity of associated species and are characterized by slow growth and accumulation rates (Blake \& Maggs 2003; Bosence \& Wilson 2003). Few attempts have been made to quantify the spatial extent of modern rhodolith facies, despite their importance and common occurrence (Hetzinger et al. 2006). Since the development of modern acoustic ground discrimination systems, which allow the distinction of different sediment types based on their geophysical properties (Riegl \& Purkis 2005), a limited number of studies have quantified rhodolith facies extent (Birkett et al. 1998; Hetzinger et al. 2006).
The goals of the present study are: 1) to conduct quantitative acoustic mapping of the largest rhodolith-dominated shelf area in the Gulf of California using an acoustic ground discrimination system; 2) to correlate acoustic mapping with sediment data; and 3) to characterize physical conditions favorable for development of the rhodalgal carbonates. The functioning of the applied acoustic mapping method has important implications for quantifying rhodolith carbonate production in other regions, and can be applied to studies focusing on ecological and conservation aspects.

\section{REGIONAL SETTING}

The Gulf of California, Mexico, is one of the best studied regions globally with respect to extensively developed modern rhodolith-dominated carbonates (Steller \& Foster 1995; Foster et al. 1997; ReyesBonilla et al. 1997; Marrack 1999; RiosmenaRodríguez et al. 1999; Steller et al. 2003; Hetzinger et al. 2006). With its latitudinal extent from $23^{\circ} \mathrm{N}$ to $30^{\circ} \mathrm{N}$, the evaporative basin of the Gulf of California spans the warm-temperate/subtropical realm, is characterized by seasonal upwelling and encompasses nutrient regimes from oligo-mesotrophic in the south to eutrophic in the north (Alvarez-Borrego 2010; Fig. 1). Carbonate production ranges from coral-reef dominated shallow-water areas in the south to rhodolith-dominated, inner shelf carbonate production in the central gulf, and to molluscanbryozoan inner- to outer-shelf environments in the northern Gulf (Halfar et al. 2006b).

In the central Gulf of California modern rhodolith-dominated carbonate factories develop under meso- to eutrophic conditions (Halfar et al. 2006a). Punta Chivato is the northernmost of a series of well-developed rhodolith-dominated settings in the Gulf of California. Restricted rhodolith beds, however, are found throughout the entire gulf (Steller et al. 2009; Riosmena-Rodríguez et al. 2010), but no reports of extensive beds (e.g., $>1 \mathrm{~km}^{2}$ ) contributing significant amounts of carbonate sediment exist from the extreme north and south of the gulf. The southernmost extensive Gulf of California rhodolith-dominated seafloor environ- 

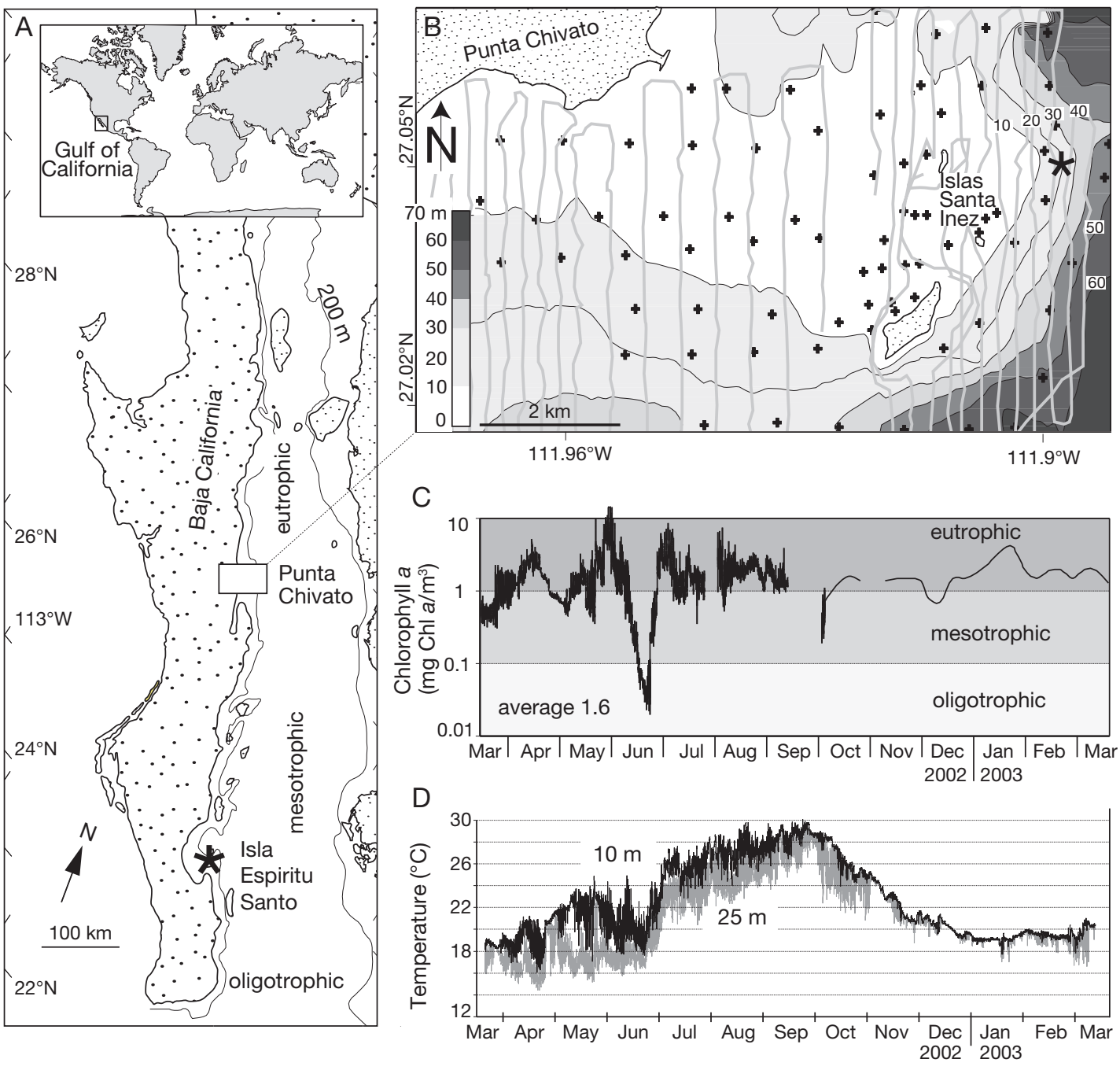

FIG. 1. - The Punta Chivato study site in the central Gulf of California: A, asterisk indicates location of southernmost extensive rhodolith bed described in Gulf of California (Marrack 1999); B, Punta Chivato bathymetry with sampling locations (+) and acoustic sediment mapping transects; asterisk indicates position of oceanographic mooring; C, Chl a measurements (10 m water depth - in situ measurements March-September; SeaWiFS data October-March); D, high-resolution in situ temperatures (from Halfar et al. 2006a).

ment described is located near Isla Espiritu Santo $400 \mathrm{~km}$ to the south of Punta Chivato (Marrack 1999) occupying an area of $20 \mathrm{~km}^{2}$ (Halfar et al. 2001; Fig. 1).

Punta Chivato itself is a small headland in the middle of the east coast of the Baja California Peninsula that extends several kilometers into the Gulf of California (Libbey \& Johnson 1997). The shelf of Punta Chivato is flat with a mean depth of 13 m west of Islas Santa Inez (Fig. 1). Even though partly protected by this group of three islands and the headland of Punta Chivato to the north, the studied shelf is subjected to seasonally shifting winds and high wave energies from the north, east and south (Simian \& Johnson 1997; Johnson \& Ledesma-Vasquez 1999). A brief overview of the 
A

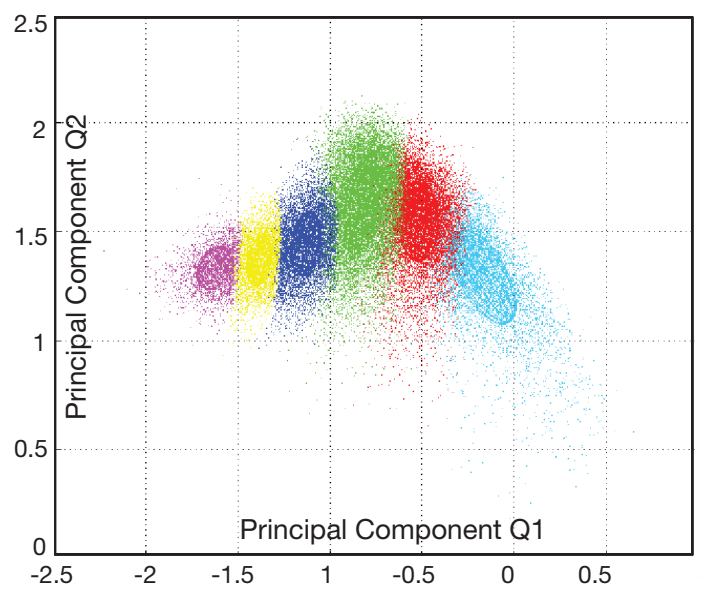

B

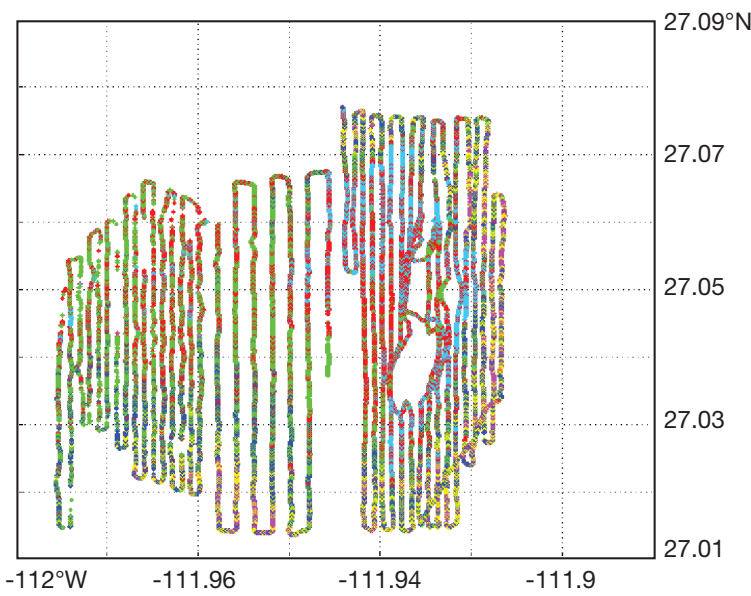

FIG. 2. - A, scatterplot of acoustic diversity of survey data; each datapoint represents principle component loadings of an acoustic waveform characterized by a variety of descriptors (see methods); data cloud was split into a predetermined optimal number of clusters (see Methods); cluster centroids are shown; B, spatial distribution of classified data.

Punta Chivato carbonate factory has been given by Halfar et al. (2006a), while the molluscan fauna associated with the rhodolith bed has been characterized by Cintra-Buenrostro et al. (2002) and free-living bryozoans (bryoliths) have been described by James et al. (2006).

\section{METHODS}

\section{OCEANOGRAPHY}

An oceanographic mooring with a near-surface buoy was positioned at $25 \mathrm{~m}$ depth for a one-year period from March 2002 to March 2003 containing Stowaway Tidbit temperature loggers at $25 \mathrm{~m}$ and $10 \mathrm{~m}$ and a self-contained underwater fluorometer (SCUFA, Turner Designs) at $10 \mathrm{~m}$ - the depth of prolific rhodolith formation - for recording chlorophyll $a(\mathrm{Chl} a)$ a proxy for nutrients and an indicator of seafloor light conditions (location of mooring indicated on Figure 1). All equipment logged data at hourly intervals. In addition, due to equipment failure after 7 months of deployment in situ Chl $a$ data were supplemented with remote-sensed SeaWiFS information, which was obtained for each site at weekly resolution from http://seawifs.gsfc. nasa.gov. Secchi disk light-penetration depths were measured at $c$. 3-month intervals at noon from March 2002 to March 2003. At the same time, a salinometer (37SM MicroCAT, Sea-Bird Electronics) was deployed logging salinity profiles to $50 \mathrm{~m}$ depth in 1-m intervals.

\section{SEDIMENTOLOGY}

Surface sediment grab samples $(\mathrm{n}=79)$ were collected using a Van Veen clam-shell benthic grab sampler across the entire Punta Chivato study area in water depths ranging from shallow subtidal to $65 \mathrm{~m}$ (Fig. 1). Sediments were separated into three size fractions (<63 $\mu \mathrm{m} ; 63 \mu \mathrm{m}-2 \mathrm{~mm} ;>2 \mathrm{~mm})$; each size fraction was weighed to give an approximation of grain size distribution. Groups of carbonate-producing organisms were distinguished during point counting of 40 sediment samples (150 points per sample, $>2 \mathrm{~mm}$ fraction). In addition, rhodoliths and fragments were grouped according to growth morphologies defined by Woelkerling et al. (1993) after observation under a binocular microscope. Carbonate content of all samples collected (bulk sample) was determined using a coulometer following procedures outlined in John et al. (2003). 


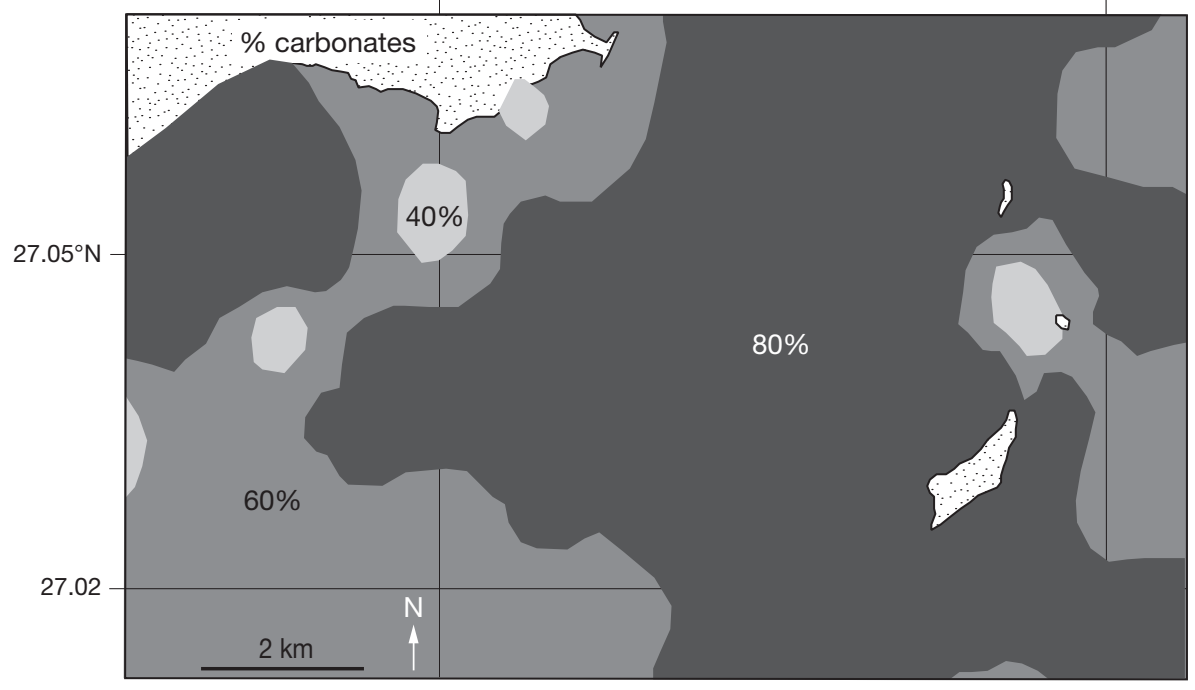

FIG. 3. - Percent carbonate content of samples (all size fractions combined).

\section{ACOUSTIC MAPPING}

Acoustic mapping was conducted using a computerbased QTC View mapping system (Quester Tangent Corporation) in conjunction with a single beam echosounder. The system interprets the characteristics of the returning waveform reflected from the seafloor to generate signal classifications based on the diversity of acoustic responses of different seafloor types. Hence, as discussed in detail by Riegl \& Purkis (2005) and Riegl et al. (2007) it is sensitive to sediment composition and/or benthic assemblages (e.g., signal differs between hard vs soft bottom). For the identification of facies this study concentrated on using $200 \mathrm{kHz}$ echosounder data. This relatively high-frequency and short wave-length signal enters little into the substratum and is primarily reflected at the sediment surface. Rugose surfaces create strong scatter, which tends to be well-visible when total acoustic diversity is evaluated (Moyer et al. 2005). Since rhodolith-dominated seafloor environments are relatively rugose structures, it was reasoned that acoustic diversity above rhodolith-dominated environments would be strongly influenced by a scatter component. $170 \mathrm{~km}$ of transect lines were acquired at a cruise speed of 5 knots and line spacing was $200 \mathrm{~m}$ ( $400 \mathrm{~m}$ in the center of the study area; Fig. 1). In QTC Impact software, the echoes were digitized, subjected to Fourier and wavelet analysis and were analyzed for kurtosis, area under the curve, spectral moments, and other variables by the acquisition software (Legendre et al. 2002). After being normalized they were subjected to principal components analysis (PCA) in order to eliminate redundancies and noise. The first three principal components of each echo were retained (called $Q$ values), as they contain the majority of the information (Fig. 2). Datapoints were projected into pseudo-three-dimensional space along these three components, where they were then subjected to cluster analysis using a Bayesian approach. In clustering, the user decides on the number of desirable clusters and also chooses which cluster to split and how often. Decisions are based on a series of indices that allow detection of optimal number of clusters (Legendre et al. 2002; Riegl \& Purkis 2005). The class-categorized data were imported into a Geographic Information System (ESRI ArcGISTM 8.2) with the objective to map the distribution of the different clusters spatially over the surveyed area (Fig. 2). After regridding the irregular survey data to a regular grid, nearest-neighbour interpolation was used to provide full coverage of acoustic 


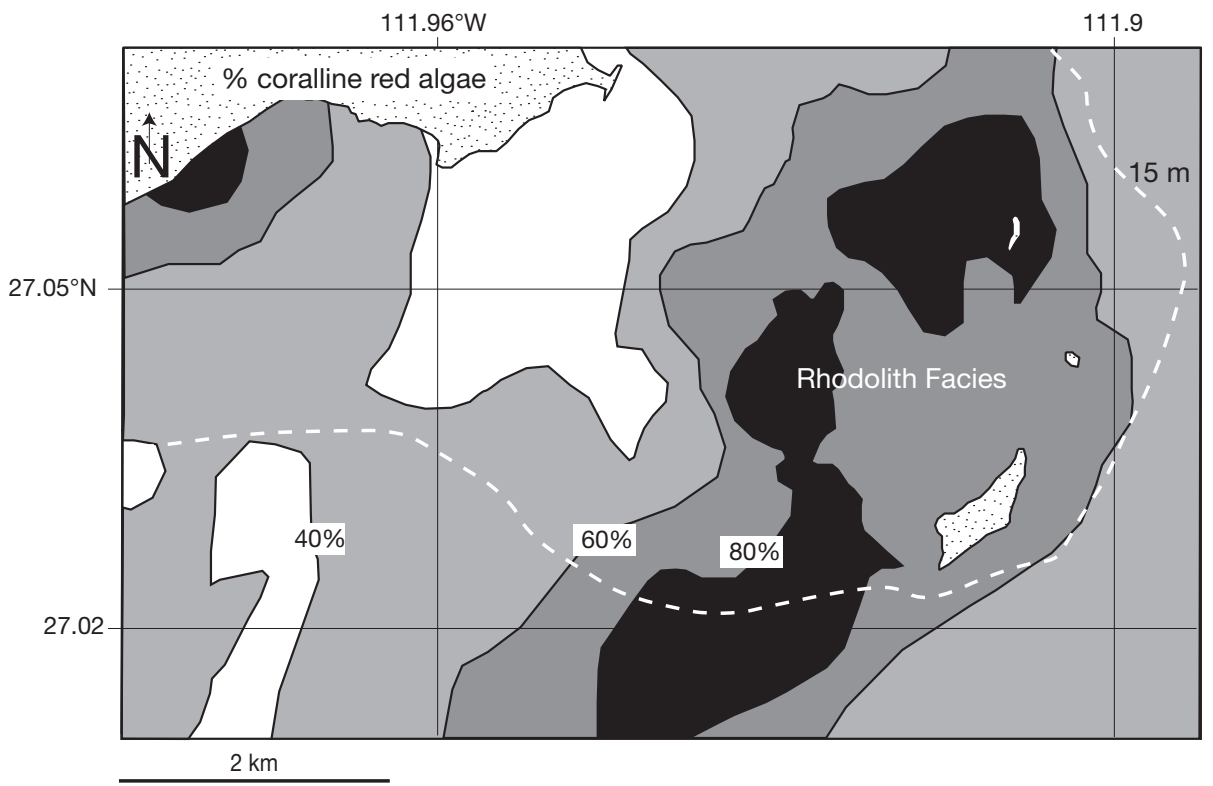

FIG. 4. - Distribution of rhodolith components (> $60 \%$ rhodolith components in $>2 \mathrm{~mm}$ fraction). Dashed white line shows $15-\mathrm{m}$ depth contour.

data also in between survey lines (Hetzinger et al. 2006). In order to allow for gradations between the classes, they were arranged in a logical order so that fractional classes could be seen as gradations along a surface roughness ramp (class 1-6 decreasing surface roughness). Spatially interpolated data were compared to qualitative groundtruthing information, which was obtained from sediment samples and by using an underwater video camera and SCUBA at selected locations.

\section{RESULTS}

\section{OCEANOGRAPHY}

Based on quarterly measurements to $30 \mathrm{~m}$ depth, salinity at each of the four carbonate producing settings fluctuated little throughout the year and was centered at 35.2\%o (Table 1). A shallow thermocline was present from April through October with thermocline depths varying between 14 and $27 \mathrm{~m}$ (Fig. 1; Table 1). Ocean temperatures above the thermocline ranged from 17 to $30^{\circ} \mathrm{C}$ and are characteristic of the warm-temperate realm. Chlorophyll $a$ concentrations fluctuated widely throughout the year and within individual months ranging from oligotrophic through eutrophic conditions (Fig. 1). For most of the year, however, eutrophic conditions prevailed (average $1.6 \mathrm{mg} \mathrm{Chl} \mathrm{a} / \mathrm{m}^{3}$ ) with high phytoplankton biomass restricting depth of light penetration as evidenced by a minimum Secchi disk depth of $8 \mathrm{~m}$ (range 8-18 m; Table 1). Similar Secchi disk depths of 9-15 m have been reported from the Bahía Concepción rhodolith bed $50 \mathrm{~km}$ to the south of Punta Chivato (Foster et al. 1997). Double Secchi disc depth (e.g., minimum 16 m at Punta Chivato) commonly defines the depth of the euphotic zone where $<1 \%$ of surface irradiance penetrates (Holmes 1970).

\section{The Punta Chivato carbonate factory}

Owing to a lack of input of terrigenous material from the arid Baja California Peninsula, carbonate content averages $79 \%$ in all bulk samples (Fig. 3). Coralline algae in the form of rhodoliths were the most abundant carbonate constituents in the $>2 \mathrm{~mm}$-fraction (38\% of total carbonate producers). Entire living and fragmented rhodoliths were encountered throughout the study area, however, 
TABLE 1. - Physical oceanographic parameters measured at Punta Chivato.

\begin{tabular}{|c|c|c|c|c|c|c|}
\hline & $\begin{array}{l}\text { Salinity above } \\
\text { thermocline (\%o) }\end{array}$ & $\begin{array}{l}\text { Thermocline } \\
\text { depth }(\mathrm{m})\end{array}$ & $\begin{array}{l}\text { Temperature } \\
\text { at } 10 \mathrm{~m}\left({ }^{\circ} \mathrm{C}\right)\end{array}$ & $\begin{array}{l}\text { Temperature } \\
\text { at } 25 \mathrm{~m}\left({ }^{\circ} \mathrm{C}\right)\end{array}$ & $\begin{array}{l}\text { Chlorophyll a } \\
(\mathrm{mg} \mathrm{Chl} \mathrm{a/m})\end{array}$ & $\begin{array}{c}\text { Secchi Disk } \\
\text { depth }(m)\end{array}$ \\
\hline March 2002 & 35.2 & 27 & 19 & 18 & 0.8 & 9.5 \\
\hline Aug 2002 & 35.3 & 14 & 28 & 25 & 3 & 8 \\
\hline Nov 2002 & 35.3 & $>50$ & 26 & 25 & 1 & 9 \\
\hline Jan 2003 & 35.3 & $>50$ & 19 & 19 & 4 & 18 \\
\hline March 2003 & 35.3 & $>50$ & 20 & 19 & 2 & 11 \\
\hline
\end{tabular}

they were widespread from the shallow subtidal zone to inner shelf depth (to $20 \mathrm{~m}$ ). With concentrations of $>60 \%$ of total carbonate producers rhodolith material was most abundant west of Islas Santa Inez and close to the shore in the northwestern part of the Punta Chivato shelf at water depths $<10 \mathrm{~m}$ (Fig. 4). An exception was the southern part of the Punta Chivato shelf where an accumulation of more than $60 \%$ rhodolith fragments (out of total \% carbonate producers) reached to $40 \mathrm{~m}$ water depth. Rhodolith growth morphologies - indicators of environmental conditions and energy regimes - can be grouped according to a classification scheme modified from Woelkerling et al. (1993) into 85\% fruticose (branching) growth forms, 9\% lumpy (crowded, contiguous and rarely branched) forms and 6\% fragile foliose (lamellate branch) forms (Fig. 5). While the fruticose forms were evenly distributed throughout the study area, fragments of small lumpy rhodoliths were found in more than $60 \mathrm{~m}$ water depth east of Islas Santa Inez. In general the occurrences of fruticose and lumpy rhodoliths were inversely correlated. Foliose rhodoliths were concentrated in the south and encrusting coralline algae are found mainly along the rocky shoreline of Punta Chivato.

Bivalves made up 35\% of all carbonate producers, whereas gastropods accounted for $8 \%$ of the carbonates (Fig. 5). 11\% of the carbonate constituents were bryozoans, most of which were located in the deeper part of the study area east of Islas Santa Inez. Hence, bryozoan abundance was strongly controlled by depth, reaching $>40 \%$ below $30 \mathrm{~m}$ and $>60 \%$ below $50 \mathrm{~m}$ (out of total \% carbonate producers). Encrusting, branching and free-living (Cupuladriid) bryozoans represented the most common growth morphologies. Carbonate producers such as serpulids, zooxanthellate corals and barnacles made up less than $2 \%$ each of total carbonate producers (Fig. 5). The predominant grain size range on the Punta Chivato shelf was from $>63 \mu \mathrm{m}-2 \mathrm{~mm}$ (sand fraction). Only in locations where rhodoliths and their fragments made up $>60 \%$ of the carbonate biota did the sand fraction account for less than $60 \%$ of the total sediment, while gravel size components comprised $>40 \%$ of the sediment (Fig. 6). Hence, coarse grain sizes were correlated with high abundances of rhodoliths and rhodolith-derived fragments.

\section{Punta Chivato RHODOLiTH FaCies}

The above shown abundance and distribution data of rhodoliths and rhodolith-derived fragments allowed for delimiting an extensive area of dense coverage of rhodoliths (defined here as $>60 \%$ rhodoliths and fragments in the $>2 \mathrm{~mm}$-fraction - based on total carbonate producers) west of Islas Santa Inez (Fig. 4). According to a spatial interpolation of the percentage of coralline algae, most of the Punta Chivato rhodoliths are largely confined to the $15 \mathrm{~m}$ depth contour, except for a tongue of rhodolith sediment extending to the south below $15 \mathrm{~m}$ (Fig. 4). A region of high abundances of rhodoliths near the coastline along the northwestern part of Punta Chivato was not well defined due to low sample coverage $(n=2)$ and bottom observations did not reveal significant amounts of living rhodoliths (Fig. 4).

\section{ACOUSTIC MAPPING}

Based on sediment characteristic and seafloor observations in combination with principal component analysis of acoustic return signals, six acoustic seafloor facies were distinguished (Fig. 7; Table 2). Acoustic facies 1 to 3 were dominated by rho- 


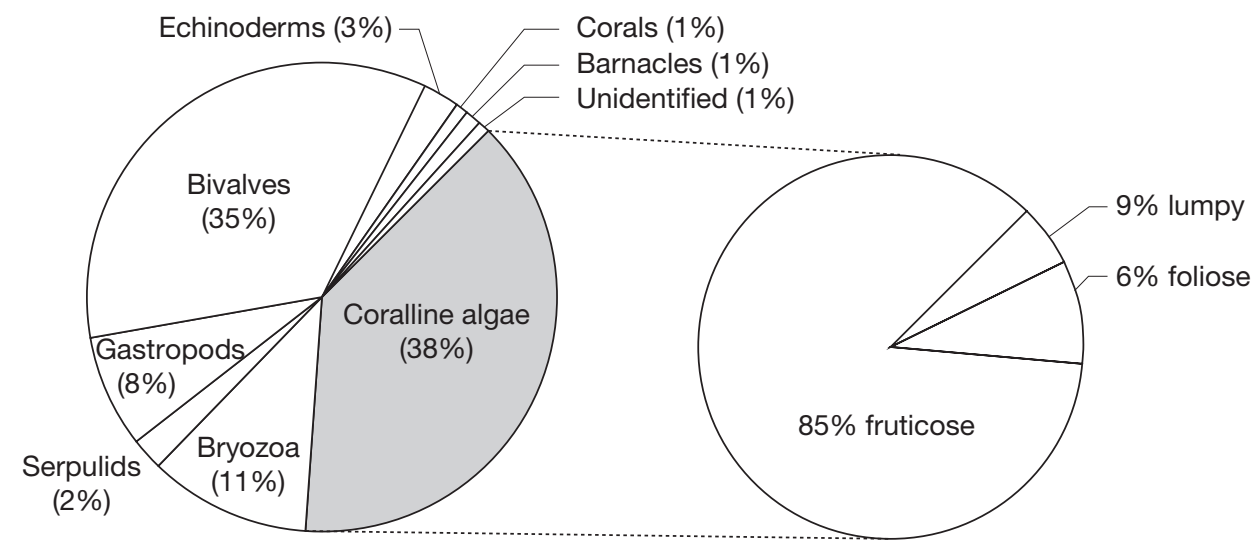

FIG. 5. - Average percentages of biogenic constituents of Punta Chivato and composition of rhodolith subcategories (> $2 \mathrm{~mm}$ fraction, $n=40$ ).

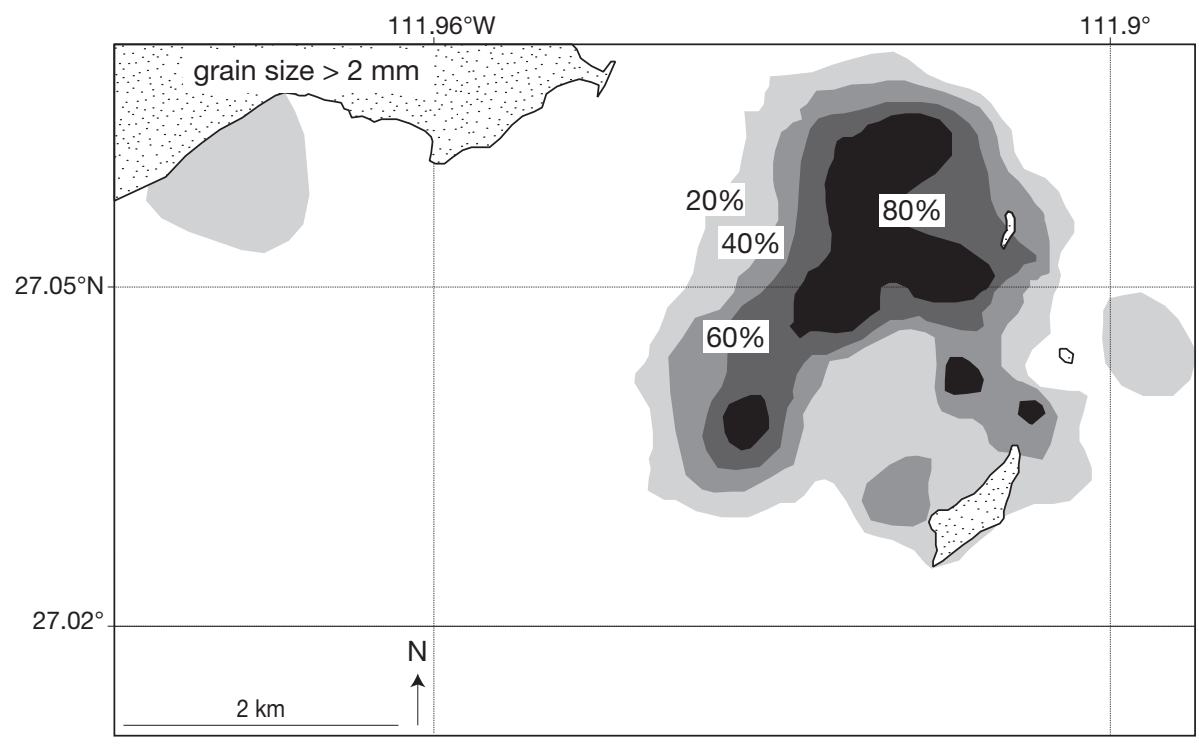

FIG. 6. - Distribution of sediment fraction $>2 \mathrm{~mm}$. Coarse fraction gives indication on location of rhodolith beds.

doliths and surrounded the islands of Santa Inez. These facies largely overlapped with the location of the rhodolith-dominated seafloor environment as defined by sediment analysis. All three facies had a high carbonate content $(>93 \%)$ and were characterized by their coarse grain size. Even though actual differences in the three acoustic facies were subtle, acoustic facies 2 represented the center of the rhodolith-dominated area with highest amounts of rhodolith material. Acoustic facies 1 and 2 exhibited the coarsest material. Groundtruthing indicated that living rhodoliths were abundant in these two acoustic facies. Acoustic facies 1 , which was closely associated with the group of three islands, differed from facies 2 in the frequent occurrence of rocky nearshore outcrops, causing a difference in the reflected acoustic signal. Facies 2 was defined as a rhodolith-dominated facies, whereas facies 1 was 
a combined rhodolith-dominated - hard-substrate facies. Facies 3 surrounded the rhodolith-dominated facies and was termed a marginal rhodolith-dominated facies. This facies was characterized by lower abundances of rhodoliths and higher percentages of bivalves. Hence, facies 3 outlined the limits of the rhodolith-dominated area and likely contained material transported from acoustic facies 1 and 2 . Together, facies 1 to 3 occupy $21 \%$ of the mapped area or $17 \mathrm{~km}^{2}$. Facies 4 to 6 showed a distinctly different acoustic return signal and represented areas of high abundances of bivalves mixed with up to $31 \%$ fine non-carbonate material. These facies together occupied more than $3 / 4$ of the Punta Chivato shelf and were found close to shore (facies 5 ) or largely in deeper water (facies 4). Acoustic facies 3 was also present south of the headland of Punta Chivato, however, in the absence of extensive rhodolith cover (as observed by groundtruthing and sediment sampling; sediment consists of $86 \%$ bivalves and $6 \%$ rhodolith material) this appeared to largely be an erroneous interpolation of the acoustic data set.

\section{DISCUSSION}

\section{ACOUSTIC MAPPING AND SEDIMENTOLOGY OF THE PunTa Chivato CARbONATE SYSTEM}

The carbonate factory occupies an area of $80 \mathrm{~km}^{2}$ and is therefore the most extensive carbonate factory in the Gulf of California known to date. Due to an arid hinterland, and low terrigenous input siliciclastic material is negligible at this site away from the coastlines and above $40 \mathrm{~m}$ depth, which is the maximum depth of prolific carbonate formation. The associations of carbonate producing organisms on the Punta Chivato shelf are dominated by rhodoliths and can be defined as rhodalgal carbonates sensu Carannante et al. (1988).

Acoustic mapping shows that the rhodolithdominated area occupies c. $21 \%$ or $17 \mathrm{~km}^{2}$ of the study area (facies 1-3). The location of the acoustically mapped rhodolith-dominated area closely corresponds to the distribution of coarse grain sizes $>2 \mathrm{~mm}$. While both the acoustic map and the coarse grain size map overlap, there is a discrepancy with the spatial distribution of rhodoliths and rhodolith fragments, which extends to the south (Figs 4-7). The reason for the poor overlap is that the southern tongue of high percentages of rhodoliths represents allochthonous and broken up rhodolith material, that contains few living rhodoliths, and high numbers of fragments $>2 \mathrm{~mm}$. This material is interpreted as having been transported by currents and storms from the north and east away from the living rhodolith bed and redeposited downcurrent in up to $40 \mathrm{~m}$ water depth. This interpretation is confirmed by bottom observations during groundtruthing, indicating low coverage of living rhodoliths on the deeper shelf. Hence, both the grain size distribution and the acoustic map give a better representation of the position and extent of the rhodolith-dominated area than the distribution of rhodoliths and rhodolith-derived fragments as determined by point counting. Reasons are that the predominant grain size has an important influence on the acoustic return signal (Legendre et al. 2002; Riegl \& Purkis 2005). Sediments containing entire rhodoliths will therefore have a different acoustic character as sediments with mainly rhodolith fragments, or sediments dominated by molluscs or bryozoa. In fact, acoustic sediment mapping has previously been shown to be an excellent approach for detecting and delimiting the extent of rhodolith facies (Birkett et al. 1998; Hetzinger et al. 2006; Ierodiaconou et al. 2011).

\section{Punta Chivato RHOdOLITH ENVIRONMENT}

While modern rhodolith beds of varying size have been described from throughout the modern Gulf of California (see distribution map in Steller et al. 2009 and Riosmena-Rodríguez et al. 2010), sediment-forming rhodolith-dominated environments are restricted to the central portion between Punta Chivato and Isla Espiritu Santo (Halfar et al. 2006; Fig. 1). Gulf of California rhodoliths generally occur in two main settings: 1) gently sloping, subtidal soft bottoms with moderate wave action (wave beds; $<12 \mathrm{~m}$ deep); and 2) relatively level bottoms in channels with tidal currents (current beds; $>12 \mathrm{~m}$ ) (Foster et al. 1997). In both settings, rhodoliths are protected from smothering by fine sediments through tidal currents or wave action (Marrack 1999). The majority of the Punta Chivato rhodolith 
TABLE 2. - Characteristics of acoustic facies.

\begin{tabular}{|c|c|c|c|c|c|c|}
\hline Acoustic Facies & 1 & 2 & 3 & 4 & 5 & 6 \\
\hline Depth range & $5-25 \mathrm{~m}$ & $5-15 \mathrm{~m}$ & $0-45 \mathrm{~m}$ & $15->65 \mathrm{~m}$ & $0-25 \mathrm{~m}$ & $0-10 \mathrm{~m}$ \\
\hline $\begin{array}{l}\text { Main carbonate } \\
\text { producers }\end{array}$ & $\begin{array}{c}\text { Rhodoliths } \\
\text { bryozoa }\end{array}$ & $\begin{array}{c}\text { Rhodoliths bryo- } \\
\text { zoa bivalves }\end{array}$ & $\begin{array}{c}\text { Rhodoliths } \\
\text { bivalves }\end{array}$ & $\begin{array}{l}\text { Bivalves rhodoliths } \\
\text { gastropods bryozoa }\end{array}$ & $\begin{array}{l}\text { Bivalves } \\
\text { rhodoliths }\end{array}$ & $\begin{array}{l}\text { Bivalves } \\
\text { rhodoliths }\end{array}$ \\
\hline $\begin{array}{l}\text { Average carbon- } \\
\text { ate content }\end{array}$ & $93 \%$ & $94 \%$ & $94 \%$ & $79 \%$ & $79 \%$ & $79 \%$ \\
\hline $\begin{array}{l}\text { Dominant } \\
\text { grain size }\end{array}$ & $>2 \mathrm{~mm}$ & $>2 \mathrm{~mm}$ & $63 \mu \mathrm{m}-2 \mathrm{~mm}$ & $63 \mu \mathrm{m}-2 \mathrm{~mm}$ & $63 \mu \mathrm{m}-2 \mathrm{~mm}$ & $63 \mu \mathrm{m}-2 \mathrm{~mm}$ \\
\hline $\begin{array}{l}\text { Median grain } \\
\text { size }(\phi)\end{array}$ & -2 to -1 & -2 & 0 & $1-2$ & $1-2$ & $1-2$ \\
\hline Spatial coverage & $2 \%$ & $13 \%$ & $6 \%$ & $47 \%$ & $30 \%$ & $3 \%$ \\
\hline Facies name & $\begin{array}{l}\text { Rhodolith- } \\
\text { hard } \\
\text { substrate }\end{array}$ & $\begin{array}{l}\text { Rhodolith- } \\
\text { dominated }\end{array}$ & $\begin{array}{l}\text { Marginal } \\
\text { rhodolith- } \\
\text { dominated }\end{array}$ & $\begin{array}{r}\text { Fine-grained } \\
\text { molluscan }\end{array}$ & $\begin{array}{c}\text { Transitional } \\
\text { bivalve- } \\
\text { rhodolith }\end{array}$ & Bivalve \\
\hline
\end{tabular}

bed is shallower than $15 \mathrm{~m}$, and can be classified as a wave-dominated rhodolith bed. This finding is in contrast to Cintra-Buenrostro et al. (2002) who describe the Punta Chivato rhodolith beds as generally occurring below $12 \mathrm{~m}$, without, however, giving quantitative or bathymetric data on rhodolith distribution. On a global scale, the majority of rhodolith beds are most commonly found in less than $30 \mathrm{~m}$ water depth (e.g., Bosellini \& Ginsburg 1971; Freiwald \& Henrich 1994; Piller \& Rasser 1996; Perry 2005; Basso et al. 2009).

Rhodolith growth forms and structure can be used as environmental indicators (Bosence 1983; Basso 1998; Steller et al. 2003; Basso et al. 2009). Most of the fruticose rhodoliths - the most common growth form in the study area - are fragmented by water motion. The fact that only fruticose forms are fragmented is an indication for weak water motion. While protuberance degree (Basso et al. 2009) and thickness of individual branches generally decreases with increasing water depth and decreasing energy (Steller et al. 2003), there is no depth-related trend in occurrences of fruticose rhodoliths in our study. This is further evidence for low-energy conditions in shallow-water. Fruticose massive morphologies were found within the rhodolith facies, but also in deeper samples. Lumpy forms usually occur in shallow-water only, where they are resistant to wave energy (Foster et al. 1997). The abundance of these forms in deeper water at Punta Chivato most likely reflects the allochthonous character of redeposited rhodoliths.

The associated calcareous fauna of the rhodolithdominated settings in the Gulf of California exhibits a north-south gradient (Halfar et al. 2006a). The transition from cold, nutrient-enriched, to warmer, nutrient-impoverished regions, is manifested in rhodolith settings in the northern gulf exhibiting higher abundances of bivalves and bryozoa, whereas rhodoliths in the south are frequently associated with zooxanthellate corals (Reyes-Bonilla et al. 1997; Hetzinger et al. 2006). As minimum monthly sea surface temperatures (SSTs) between Punta Chivato $\left(16^{\circ} \mathrm{C}\right)$ and Isla Espiritu Santo $\left(16.5^{\circ} \mathrm{C}\right.$ - the location of the southermost described extensive rhodolith bed in the Gulf of California; Marrack 1999) are similar, they are unlikely to be responsible for the different percentages of associated calcifiers.

Nutrients, however, play a significant role in the distribution pattern of Gulf of California rhodoliths and associated carbonate producers, due to their effect on light-penetration. While nutrients themselves are not limiting the development of rhodolith facies (Steller et al. 2009), increased nutrients stimulate phytoplankton growth. This is reflected by increased $\mathrm{Chl} a$ values under high-nutrient conditions. Phytoplankton abundance in turn exerts a significant influence on light reaching the seafloor and, hence, the growth of light-dependent rhodoliths (Halfar et al. 2006). In fact, there is an 


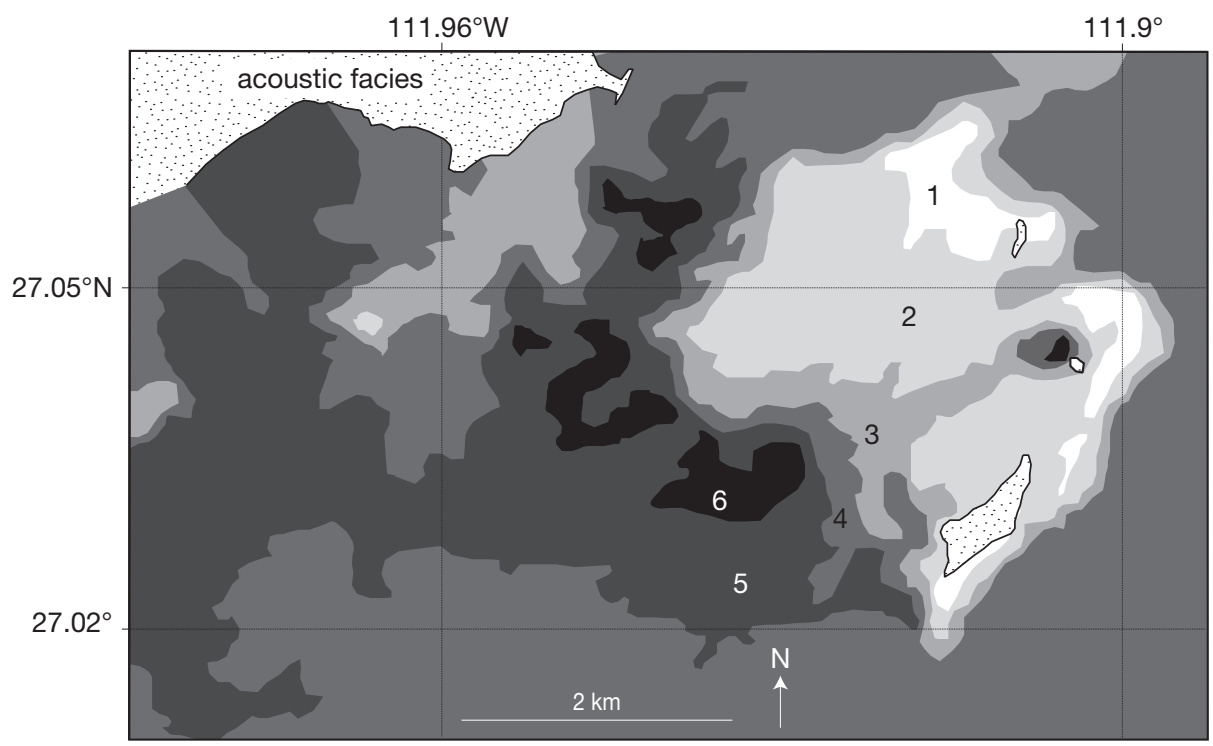

FIG. 7. - Spatial distribution of acoustic facies and respective characteristics (gradations along a surface roughness ramp - class 1-6 decreasing surface roughness). Facies description shown in Table 2.

intimate link between nutrients and depth of the light-dependent euphotic zone (Hallock 1987). The decreasing depth of the euphotic zone in the Gulf of California (average depth of euphotic zone in the south is $26 \mathrm{~m}$; in the north $16 \mathrm{~m}$; Halfar et al. 2006a) is accompanied by increasing concentrations of chlorophyll a (Halfar et al. 2006a). Living rhodoliths only occur where light on the seafloor is suitable for growth (Steller et al. 2009; RiosmenaRodríguez et al. 2010). Generally, the maximum depth for growth is assumed to be at the limit of the euphotic zone (Foster et al. 1997), which has a minimum depth of $16 \mathrm{~m}$ (average $22 \mathrm{~m}$ ) at Punta Chivato. Accordingly, the maximum average depth of the spatially extensive rhodolith-dominated acoustic facies 2 at Punta Chivato is $15 \mathrm{~m}$.

As light penetration decreases with increasing nutrients and phytoplankton biomass in the northwestern gulf (Alvarez-Borrego 2010), shallow seafloor environments suitable for development of extensive rhodolith facies become sparse along this steep rift-basin ocean margin. In contrast, the deepest Gulf of California rhodolith occurrences are found in the south (Riosmena-Rodríguez et al. 2010) where nutrients are lowest and light penetra- tion is highest. In the southernmost gulf, however, the absence of extensive and carbonate-sediment producing rhodolith-dominated facies is due to the presence of fast-growing zooxanthellate corals, which can dominate rhodoliths for space under high temperature and low-nutrient conditions (Riosmena-Rodríguez et al. 2010).

\section{CONCLUSION}

The Punta Chivato rhodalgal carbonate factory is dominated by an extensive wave-dominated rhodolith facies forming within the euphotic zone in less than $15 \mathrm{~m}$ water depth. The location of the acoustically mapped rhodolith-dominated facies closely corresponds to the distribution of coarse grain sizes $>2 \mathrm{~mm}$ due to the predominant grain size having an important influence on the acoustic return signal. Hence, entire rhodoliths have an acoustic character distinct from surrounding sediments. Acoustic seafloor mapping can therefore be used to rapidly and accurately map and quantify seafloor rhodolith environments. This is important, as rhodolith environments globally have been rec- 
ognized as complex habitats supporting rich and diverse benthic communities, including commercially exploited species, and are being considered as marine conservation areas in different regions of the world (Steller et al. 2009).

\section{Acknowledgements}

This study was supported by the Volkswagen Stiftung, Federal Republic of Germany (grant I/77446) to JH and LGO. Permission to collect sediment samples was granted by SEMARNAT (permit 300702-613-03). BR was supported by NOAA grant NA03NOS4260046 to NCRI, JH by a NSERC Discovery Grant, and SH by a Feodor Lynen Fellowship (Alexander von Humboldt Foundation). We acknowledge J. Borges, G. Gutierrez, M. Strasser, $\mathrm{H}$. Torres and J. Valdez-Holguin for their support during fieldwork. Two anonymous reviewers and V. Malécot (Angers) are acknowledged for their critical review of this manuscript.

\section{REFERENCES}

Alvarez-Borrego S. 2010. - Physical, chemical and biological oceanography of the Gulf of California, in BRUSCA R. C. (ed.), The Gulf of California: Biodiversity and Conservation. The University of Arizona Press, Tucson: 24-48.

BASSO D. 1998. - Deep rhodolith distribution in the Pontian Islands, Italy: a model for the paleoecology of a temperate sea. Palaeogeography, Palaeoclimatology, Paleoecology 137 (1-2): 173-187.

Basso D., Morbioli C. \& Corselli C. 2006. Rhodolith facies evolution and burial as response to Holocene transgression at the Pontian Islands shelf break, in PedLey M. \& CARANNANTE G. (eds), Cool-Water carbonates: depositional systems and palaeoenvironmental controls. Geological Society of London, Special Publication 255: 23-34.

Basso D., VRSAljKo D. \& Grgasovic T. 2008. — The coralline flora of a Miocene maërl: the Croatian "Litavac". Geologie Croatica 61 (2-3): 333-340.

Basso D., Nalin R. \& Nelson C. S. 2009. — Shallowwater Sporolithon rhodoliths from North Island (New Zealand). Palaios 24 (2): 92-103.

Betzler C., Brachert T. C. \& Nebelsick J. 1997. The warm temperate carbonate province: a review of the facies, zonations, and delimitations. Courier Forschungsinstitut Senckenberg 201: 83-99.

Birkett D. A., Maggs C. \& Dring M. J. 1998. -
Maërl. Volume V. An Overview of Dynamic and Sensitivity Characteristics for Conservation Management of Marine SACs. Scottish Association of Marine Science, Belfast, $116 \mathrm{p}$.

BlaKe C. \& MAGGS C. A. 2003. - Comparative growth rates and internal banding periodicity of maërl (Corallinales, Rhodophyta) from northern Europe. Phycologia 42 (6): 606-612.

Bosellini A. \& Ginsburg R. N. 1971. - Form and internal structure of Recent algal nodules (Rhodolites) from Bermuda. Journal of Geology 79 (6): 669-682.

Bosence D. W. J. 1983. — The occurrence and ecology of Recent rhodoliths - a review, in PERYT T. M. (ed.), Coated Grains. Springer-Verlag, Berlin, 225-241.

Bosence D. W. J. \& Pedley H. M. 1979. - Palaeoecology of a Miocene coralline algal bioherm, Malta. Bulletin des centres de recherches exploration-production Elf-Aquitaine 3: 463-470.

BOSENCE D. W. J. \& WiLSON J. 2003. — Maërl growth, carbonate production rates and accumulation rates in the northeast Atlantic. Aquatic Conservation: Marine and Freshwater Ecosystems 13: 21-31.

Carannante G., Esteban M., Milliman J. D. \& Simone L. 1988. - Carbonate lithofacies as paleolatitude indicators: problems and limitations. Sedimentary Geology 60 (1-4): 333-346.

Cintra-Buenrostro C. E., Foster M. S. \& Meldahl K. H. 2002. - Response of nearshore marine assemblages to global change: a comparison of molluscan assemblages in Pleistocene and modern rhodolith beds in the southwestern Gulf of California, Mexico. Palaeogeography, Palaeoclimatology, Palaeoecology 183 (3-4): 299-320.

EsTeban M. 1996. - An overview of Miocene reefs from Mediterranean areas: general trends and facies models, in Franseen E. K., Esteban M., Ward W. C. \& RouchY J.-M. (eds), Models for Carbonate Stratigraphy from Miocene ReefComplexes of Mediterranean Regions. Concepts in Sedimentology and Paleontology. Society of Economic Paleontologists and Mineralogists, Tulsa, 3-53.

Fornos J. J. \& AHR W. M. 1997. — Temperate carbonates on a modern, low-energy, isolated ramp: the Balearic Platform, Spain. Journal of Sedimentary Research 67: 364-373.

FosTER M. S. 2001. - Rhodoliths: between rocks and soft places. Journal of Phycology 37: 659-667.

Foster M. S., Riosmena-Rodriguez R., STeller D. L. \& WOELKERLING W. J. 1997. — Living rhodolith beds in the Gulf of California and their implications for paleoenvironmental interpretation, in JOHNSON M. E. \& Ledesma-VazQuez J. (eds), Pliocene Carbonates and Related Facies Flanking the Gulf of California, Baja California, Mexico. Geological Society of America Special Paper, London, 318: 127-140.

Freiwald A. \& Henrich R. 1994. - Reefal coralline 
algal build-ups within the Arctic Circle: morphology and sedimentary dynamics under extreme environmental seasonality. Sedimentology 41 (5): 963-984.

Halfar J. \& MutTi M. 2005. - Global dominance of coralline red-algal facies: a response to Miocene oceanographic events. Geology 33 (6): 481-484.

Halfar J., Godinez-Orta L., Goodfriend G. A., Mucciarone D. A., Ingle J. C. Jr. \& Holden P. 2001. - Holocene-Pleistocene carbonate sedimentation and tectonic history of the La Paz area, Baja California Sur, Mexico. Sedimentary Geology 144: 149-177.

Halfar J., Godinez-Orta L., Mutti M., ValdezHolguin J. \& Borges J. 2006a. - Carbonates calibrated against oceanographic parameters along a latitudinal transect in the Gulf of California, Mexico. Sedimentology 53 (2): 297-320.

Halfar J., Strasser M., Riegl B. \& Godinez-Orta L. 2006b. - Oceanography, sedimentology and acoustic mapping of a bryomol carbonate factory in the northern Gulf of California, Mexico, in Pedley H. M. \& CARANNANTE G. (eds), Cool-Water carbonates: depositional systems and palaeoenvironmental controls. Geological Society of London, Special Publication 255: 197-215.

Hallock P. 1987. - Fluctuations in the trophic resource continuum: a factor in global diversity cycles? Paleoceanography 2 (5): 457-471.

Hetzinger S., Halfar J., Riegl B. \& Godinez-Orta L. 2006. - Sedimentology and acoustic mapping of modern rhodolith facies on a non-tropical carbonate shelf (Gulf of California, Mexico). Journal of Sedimentary Research 76 (4): 670-682.

Holmes R. W. 1970. - The Secchi Disk in turbid coastal waters. Limnology and Oceanography 15: 688-694.

IEROdiaconou D., Monk J., RatTray A., LaURENSON L. \& VERSACE V. L. 2011. - Comparison of automated classification techniques for predicting benthic biological communities using hydroacoustics and video observations. Continental Shelf Research 31 (2): S28-S38. http://dx.doi.org/10.1016/j.csr.2010.01.012

James D. W., Foster M. S. \& O'Sullivan J. 2006. Bryoliths (Bryozoa) in the Gulf of California. Pacific Science 60 (1): 117-124.

John C. M., Mutti M. \& Adatte T. 2003. — Mixed carbonate-siliciclastic record on the North African margin (Malta) - coupling of weathering processes and mid Miocene climate. Geological Society of America Bulletin 115 (2): 217-229.

JoHnSOn M. E. \& LeDESMA-VASQUEZ J. 1999. — Biological zonation on a rocky-shore boulder deposit: Upper Pleistocene Bahia San Antonio (Baja California Sur, Mexico). Palaios 14 (6): 569-584.

JoHnSON M. E., BACKUS D. H. \& RiosmENA-ROdRIGUEZ R. 2009. - Contribution of rhodoliths to the generation of Pliocene-Pleistocene limestone in the Gulf of California, in JoHnson M. E. \& Ledesma-VASQUez J. (eds), Atlas of Coastal Ecosystems in the Western Gulf of California. University of Arizona Press, Tucson, 83-94.

Legendre P., Ellingsen K. E., BJornborn E. \& CASGRAIN P. 2002. - Acoustic seabed classification: improved statistical method. Canadian Journal of Fisheries and Aquatic Sciences 59: 1085-1089.

Libbey L. K. \& Johnson M. E. 1997. — Upper Pleistocene rocky shores and intertidal biotas at Playa La Palmita (Baja California Sur, Mexico). Journal of Coastal Research 13 (1): 216-225.

MARRACK E. C. 1999. - The relationship between water motion and living rhodolith beds in the southwestern Gulf of California, Mexico. Palaios 14 (2): 159-171.

Moyer R. P., Riegl B., Banks K. \& Dodge R. E. 2005. - Assessing the accuracy of acoustic seabed classification for mapping coral reef environments in South Florida (Broward County, USA). International Journal of Tropical Biology 53 (suppl. 1): 175-184.

Nalin R., Nelson C. S., BASSO D. \& MASSARI F. 2008. Rhodolith-bearing limestones as transgressive marker beds: fossil and modern examples from North Island, New Zealand. Sedimentology 55 (2): 249-274.

PERRY C. T. 2005. - Morphology and occurrence of rhodoliths in siliciclastic, intertidal environments from a high-latitude reef setting, southern Mozambique. Coral Reefs 24 (2): 201-207.

Piller W. E. \& Rasser M. 1996. — Rhodolith formation induced by reef erosion in the Red Sea, Egypt. Coral Reefs 15 (3): 191-198.

Pomar L., Brandano M. \& Westrhal H. 2004. Environmental factors influencing skeletal grain sediment associations: a critical review of Miocene examples from the western Mediterranean. Sedimentology 51 (3): 627-651.

Rasser M. \& Piller W. E. 2004. - Crustose algal frameworks from the Eocene Alpine Foreland. Palaeogeography, Palaeoclimatology, Palaeoecology 206 (1-2): 21-39.

Reyes-Bonilla H., Riosmena-Rodriguez R. \& Foster M. S. 1997. - Hermatypic corals associated with rhodolith beds in the Gulf of California, Mexico. Pacific Science 51 (3): 328-337.

Riegl B. M. \& PURKIS S. J. 2005. - Detection of shallow subtidal corals from IKONOS satellite and QTC View $(50,200 \mathrm{kHz}$ ) single-beam sonar data (Arabian Gulf, Dubai, UAE). Remote Sensing of Environment 95 (1): 96-114.

Riegl B., Halfar J., Purkis S. J. \& Godinez O. L. 2007. - Sedimentary facies of the eastern Pacific's northernmost reef-like setting (Cabo Pulmo, Mexico). Marine Geology 236 (1-2): 61-77.

RiosmenA-Rodríguez R., WOELKERLing W. J. \& Foster M. S. 1999. - Taxonomic reassessment of rhodolithforming species of Lithophyllum (Corallinales, Rhodophyta) in the Gulf of California, Mexico. Phycologia 38 (5): 401-417. 
Riosmena-Rodríguez R., Steller D., HinojosaArango G. \& Foster M. 2010. — Reefs that rock and roll: biology and conservation of rhodolith beds in the Gulf of California, in BRUSCA R. C. (ed.), Physical, Chemical and Biological Oceanography of the Gulf of California. The University of Arizona Press, Tucson, $23 \mathrm{p}$.

Simian M. E. \& Johnson M. E. 1997. — Development and foundering of the Pliocene Santa Ines Archipelago in the Gulf of California: Baja California Sur, Mexico, in JoHnson M. E. \& LeDESMA-VAZQUeZ J. (eds), Pliocene carbonates and related facies flanking the Gulf of California, Baja California, Mexico. Geological Society of America, Special Paper 318: 25-38.

STELler D. L. \& Foster M. S. 1995. - Environmental factors influencing distribution and morphology of rhodoliths in Bahía Concepción, B.C.S., Mexico. Journal of Experimental Marine Biology and Ecology 194 (2): 201-212.
Steller D. L., Riosmena-Rodríguez R., Foster M. S. \& ROBERTS C. A. 2003. - Rhodolith bed diversity in the Gulf of California: the importance of rhodolith structure and consequences of disturbance. Aquatic Conservation: Marine and Freshwater Ecosystems 13 (S1): S5-S20.

Steller D. L., Riosmena-Rodríguez R. \& Foster M. S. 2009. - Living rhodolith bed ecosystems in the Gulf of California, in JOHNSON M. E. \& LEDESMAVASQUeZ J. (eds), Atlas of Coastal Ecosystems in the Western Gulf of California. University of Arizona Press, Tucson: 72-82.

WiLSON M. E. J. 2002. - Cenozoic carbonates in Southeast Asia: implications for equatorial carbonate development. Sedimentary Geology 147 (3-4): 295-428.

Woelkerling W. J., Irvine L. M. \& Harvey A. S. 1993. - Growth-forms in non-geniculate coralline red algae (Corallines, Rhodophyta). Australian Systematic Botany 6: 277-293.

Submitted on 9 May 2011; accepted on 12 August 2011. 
